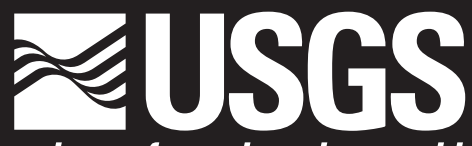

science for a changing world
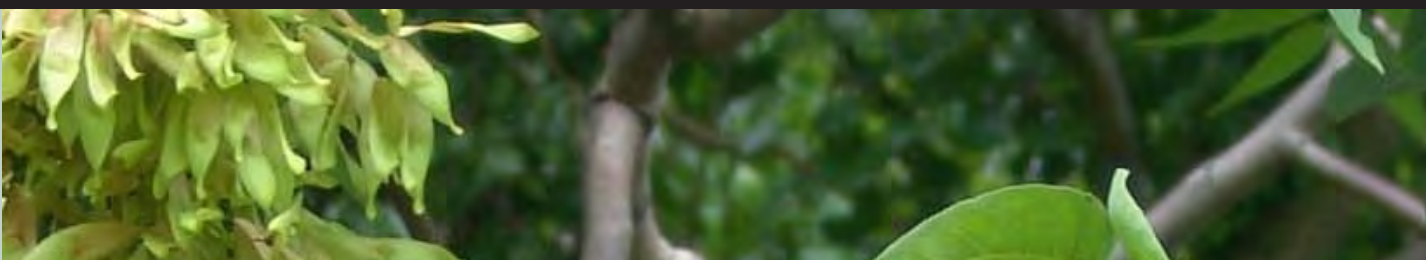

First Comprehensive List of Non-Native Species Established in Three Major Regions of the United States

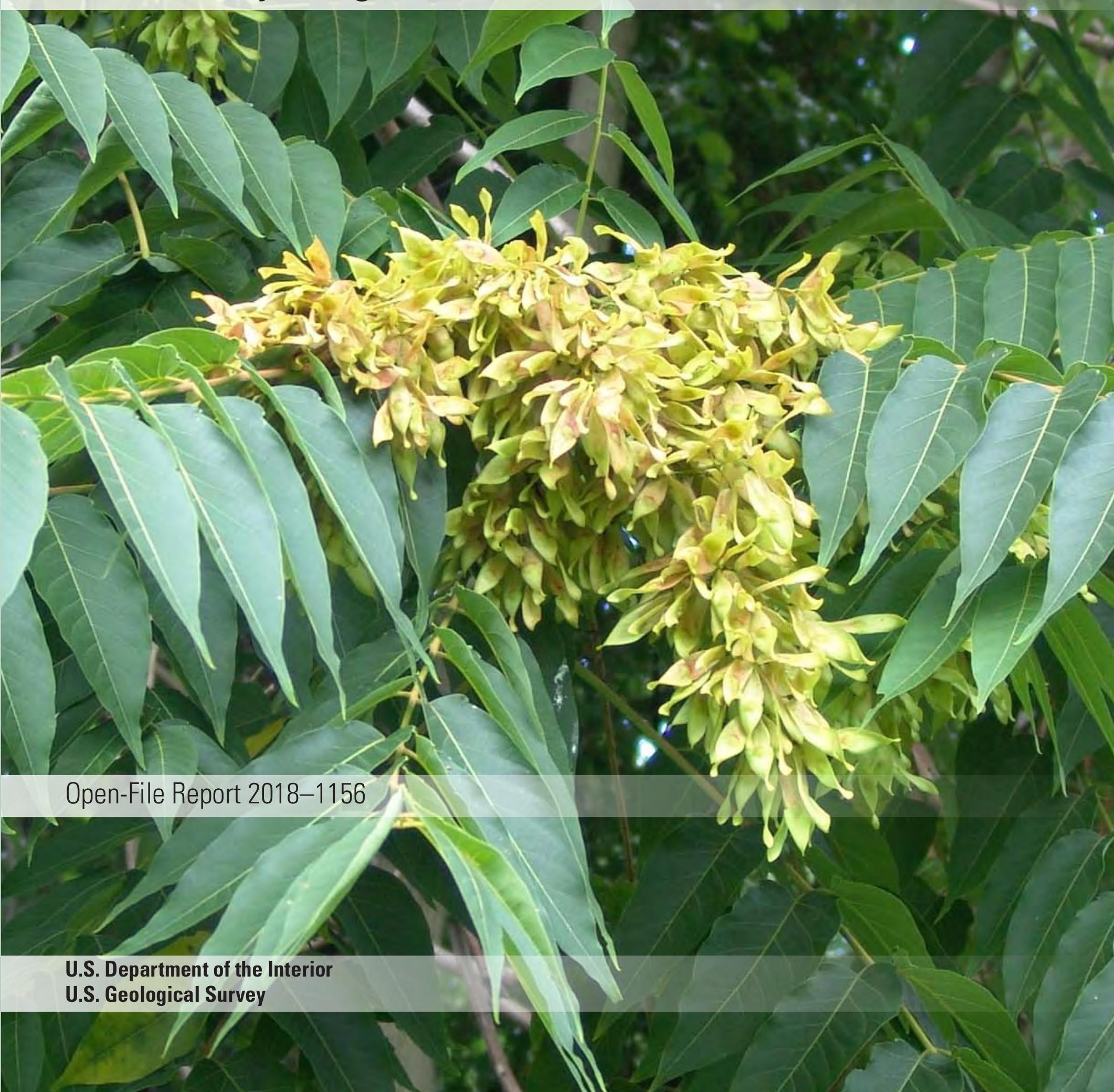


The world's most common non-native species are often first introduced as pets or for ornamental purposes and then escape into the wild. They can also arrive as hitchhikers on livestock or other commodities.

Cover. Ailanthus altissima (tree of heaven) has successfully adapted to almost all urban and rural areas of the United States. Flowering tree of heaven in Blake Lane Park, Blake Lane, Fairfax, Virginia (N 38.87579, W 77.2924) Photograph by Gerald Guala (2004, used with permission).

Back cover. Phyllostachys reticulata (Japanese timber bamboo) can form solid thickets that shade out other plants, and because it grows horizontally it is highly invasive and difficult to control. Photograph by Scott Zona. (Creative Commons 4 license). 


\section{First Comprehensive List of Non-Native Species Established in Three Major Regions of the United States}

By Annie Simpson and Meghan C. Eyler

Open-File Report 2018-1156 


\section{U.S. Department of the Interior \\ RYAN K. ZINKE, Secretary}

\section{U.S. Geological Survey James F. Reilly II, Director}

\section{U.S. Geological Survey, Reston, Virginia: 2018}

For more information on the USGS - the Federal source for science about the Earth, its natural and living resources, natural hazards, and the environment-visit https://www.usgs.gov or call 1-888-ASK-USGS.

For an overview of USGS information products, including maps, imagery, and publications, visit https://store.usgs.gov.

Any use of trade, firm, or product names is for descriptive purposes only and does not imply endorsement by the U.S. Government.

Although this information product, for the most part, is in the public domain, it also may contain copyrighted materials as noted in the text. Permission to reproduce copyrighted items must be secured from the copyright owner.

Suggested citation:

Simpson, A., and Eyler, M.C., 2018, First comprehensive list of non-native species established in three major regions of the United States: U.S. Geological Survey Open-File Report 2018-1156, 15 p., https://doi.org/10.3133/ofr20181156.

ISSN 2331-1258 (online) 


\section{Acknowledgments}

Funding for this project was provided by the U.S. Geological Survey's (USGS) Science Analytics and Synthesis Program. The authors are grateful to the following contributors who have helped substantially during the last 6 years: USGS data contributors Matthew Cannister, Gerald Guala, Natasha Kozlowski, and Reko Libby; the USGS Alaska Science Center, the USGS Pacific Island Ecological Research Center, and the USGS Wetland and Aquatic Research Center (formerly the Southeast Ecological Science Center), all of which contributed data to the list; USGS reviewers of the manuscript Wesley Daniel, Pam Fuller, Catherine Jarnevich, and Elizabeth Sellers; and seven anonymous reviewers from the journal Alien Floras and Faunas. 


\section{Contents}

Acknowledgments .......................................................................................................................ii

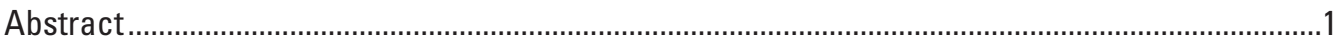

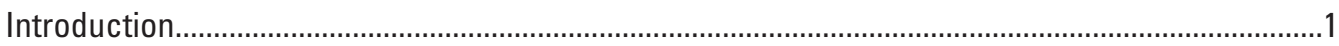

Methods for Creating the Comprehensive List of Non-Native Species ..........................................

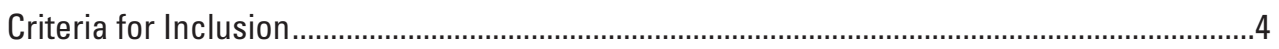

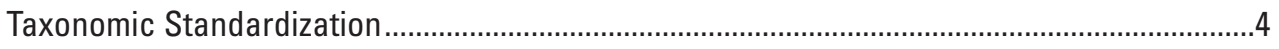

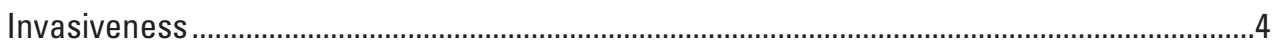

Regional Criteria

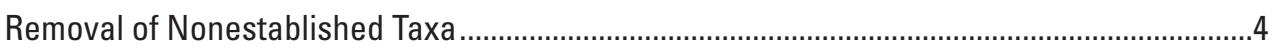

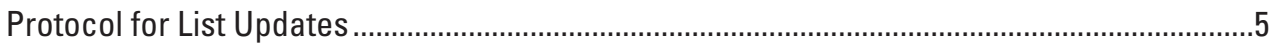

Use Case-List Comparison with a Species Occurrence Mapping Application.......................5

Results of the First Comprehensive List of Non-Native Species Established in Three Major Regions of the United States ..........................................................................................

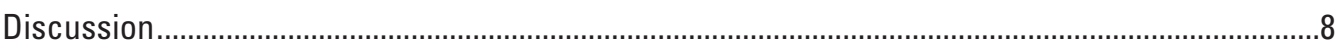

Why are National Non-Native Species Lists Important? .......................................................

Why are National Non-Native Species Lists Rare? ................................................................

National Lists of Non-Native Species-

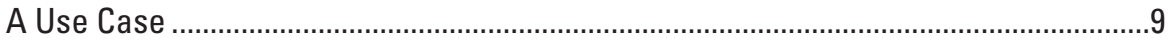

Exposing Non-Native Species Occurrences ..............................................................10

Exposing Taxonomic and Geographic Gaps................................................................10

Indic ators of Non-Native Species Richness ................................................................10

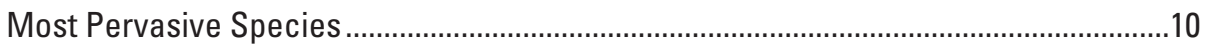

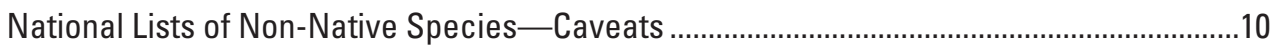

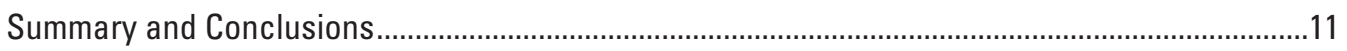

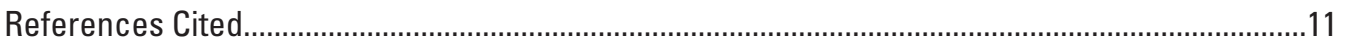

\section{Figures}

1. Methods for creating Essential Biodiversity Variable datasets. Modified from Kissling and others

2. Comparative density of non-native species richness by geographic area ........................5

3. Estimated total richness of non-native species in the United States, by county. Because southeastern Alaska recently changed city-borough mapping, the area is not shown.

4. Estimated relative richness of non-native species, as a percentage of total taxa at the county level in the United States. Because southeastern Alaska recently changed city-borough mapping, the area is not shown 


\section{Tables}

1. List of parameters for updating the non-native species list................................................

2. Search parameters and terms.......................................................................................

3. Kingdom-level taxonomic distributions of the non-native taxa in each region ................8

\section{Abbreviations}

$\begin{array}{ll}\text { BISON } & \text { Biodiversity Information Serving Our Nation } \\ \text { EBV } & \text { Essential Biodiversity Variable } \\ \text { EDDMapS } & \text { Early Detection and Distribution Mapping System } \\ \text { ITIS } & \text { Integrated Taxonomic Information System } \\ \text { USGS } & \text { U.S. Geological Survey }\end{array}$





\title{
First Comprehensive List of Non-Native Species Established in Three Major Regions of the United States
}

\author{
By Annie Simpson ${ }^{1}$ and Meghan C. Eyler ${ }^{2}$
}

\section{Abstract}

Invasive species are a subset of non-native (or alien) species, and knowing what species are non-native to a region is a first step to managing invasive species. People have been compiling non-native and invasive species lists ever since these species started causing harm, yet national non-native species lists are neither universal, nor common. Non-native species lists serve diverse purposes: watch lists for preventing invasions, inventory and monitoring lists for research and modeling, regulatory lists for species control, and nonregulatory lists for raising awareness. This diversity of purpose and the lists' variation in geographic scope make compiling comprehensive lists of established (or naturalized) species for large regions difficult. However, listing what species are non-native in an area helps measure Essential Biodiversity Variables for invasive species monitoring and mount an effective response to established non-native species. In total, 1,166 authoritative sources were reviewed to compile the first comprehensive non-native species list for three large regions of the United States: Alaska, Hawaii, and the conterminous United States (lower 48 States). The list contains 11,344 unique names: 598 taxa for Alaska, 5,848 taxa for Hawaii, and 6,675 taxa for the conterminous United States. The list is available to the public from U.S. Geological Survey ScienceBase (https://doi.org/10.5066/P9E5K160), and the intent, though not a guarantee, is to update the list as non-native species become established in, or are eliminated from, the United States. The list has been used to annotate non-native species occurrence records in the U.S. Geological Survey alltaxa mapping application, Biodiversity Information Serving Our Nation (BISON, https://bison.usgs.gov).

\section{Introduction}

Invasive species, a subset of non-native organisms, are those "whose introduction causes or is likely to cause

\footnotetext{
${ }^{1}$ U.S. Geological Survey.

${ }^{2}$ Student contractor: Baltimore, Maryland; work done under contract to the U.S. Geological Survey.
}

economic or environmental harm, or harm to human, animal, or plant health." (Executive Office of the President, 2016, p. 88610). Minimizing the effects of invasive species on vulnerable ecosystems requires comprehensive data collection and broad cooperation among scientists and policymakers (Reaser and others, 2007). The first steps to any comprehensive effort to control invasive species in an area is to ascertain what species they are and whether they are non-native (or alien) to a region. Despite being considered essential information for biodiversity science, national non-native species lists are rare (Latombe and others, 2017). Rapid dissemination of recently established and potentially harmful non-native (or alien) species records is essential for effective rapid response early in the invasion cycle when eradication is still feasible (U.S. Department of the Interior, 2016); however, a comprehensive list of non-native species for national use does not exist in the United States. The value of compiling comprehensive non-native species lists has previously been demonstrated in Europe by the development of the European Alien Species Database (http://www.europe-aliens.org; Hulme and others, 2009), which is used by governments to pass legislation related to invasive species control (Olenin and Didžiulis, 2009).

This report's comprehensive list of non-native species, compiled from data from 1,166 authoritative sources that individually are not taxonomically or geographically all inclusive, consists of taxa that are non-native to, and established (naturalized) in, three regions of the United States: Alaska, Hawaii, and the conterminous United States (lower 48 States). The term "established" as defined by Ache (2002, p. 2) means: "A species with one or more successfully reproducing or breeding (or permanent) populations in an open ecosystem, which are unlikely to be eliminated by man or natural causes. Synonym: naturalized." The list was generated following the evidence-based collection and documentation of conservation data methods by Sutherland and others (2004) and using primary peer-reviewed literature and secondary online authoritative sources that cite scientific literature. Using a regional approach, the list was generated during the last 6 years (2013-18), validated through library and internet research, and standardized taxonomically using the Integrated Taxonomic Information System (ITIS, https://www.itis.gov, supported by the U.S. Geological Survey [USGS] and other Federal partners). The intent, though not 
a guarantee, is to update the list on a regular basis and create a web service in the USGS Biodiversity Information Serving Our Nation (BISON) all-taxa mapping application, which could assist in sharing this information widely and in receiving new additions to the list from stakeholders. This list also has been used to annotate species occurrence records available through USGS BISON (https://bison.usgs.gov).

\section{Methods for Creating the Comprehensive List of Non-Native Species}

The process of compiling the data to create this national list of non-native species is detailed in a data management plan (Simpson, Mannas, and Sellers, 2018). The compilation method (fig. 1) in the data management plan was based on Kissling and others' (2017) description of how to create aggregated datasets appropriate for calculating Essential Biodiversity Variables (EBVs; Pereira and others, 2013). EBVs are a minimum set of broadly agreed upon parameters that are measured for (at least) national to global monitoring, studying, and forecasting of the variety of life in a particular habitat or ecosystem.

During the last 6 years, seven scientists extracted species names asserted to be non-native or alien to (as defined in Blackburn and others, 2014), and apparently established in (as defined by Ache, 2002), three regions of the United States from authoritative sources: peer-reviewed journal articles, books, brochures, circulars, databases, environmental assessments, technical reports, graduate theses, and websites (table 1). Commonly used search terms (table 2) were used in various combinations depending on the group of species and geographic location of focus.
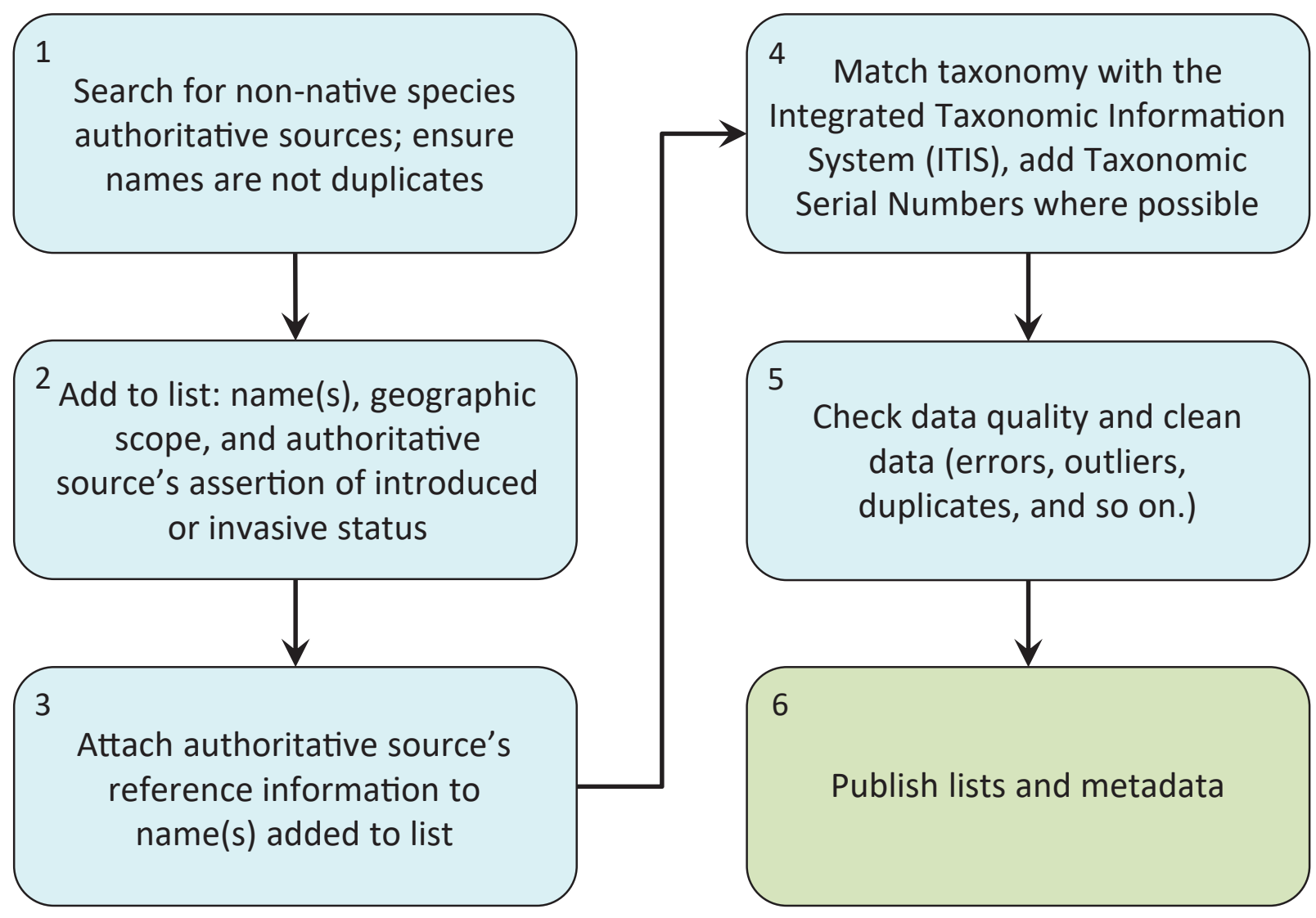

Figure 1. Methods for creating Essential Biodiversity Variable datasets. Modified from Kissling and others (2017). 
Table 1. List of parameters for updating the non-native species list.

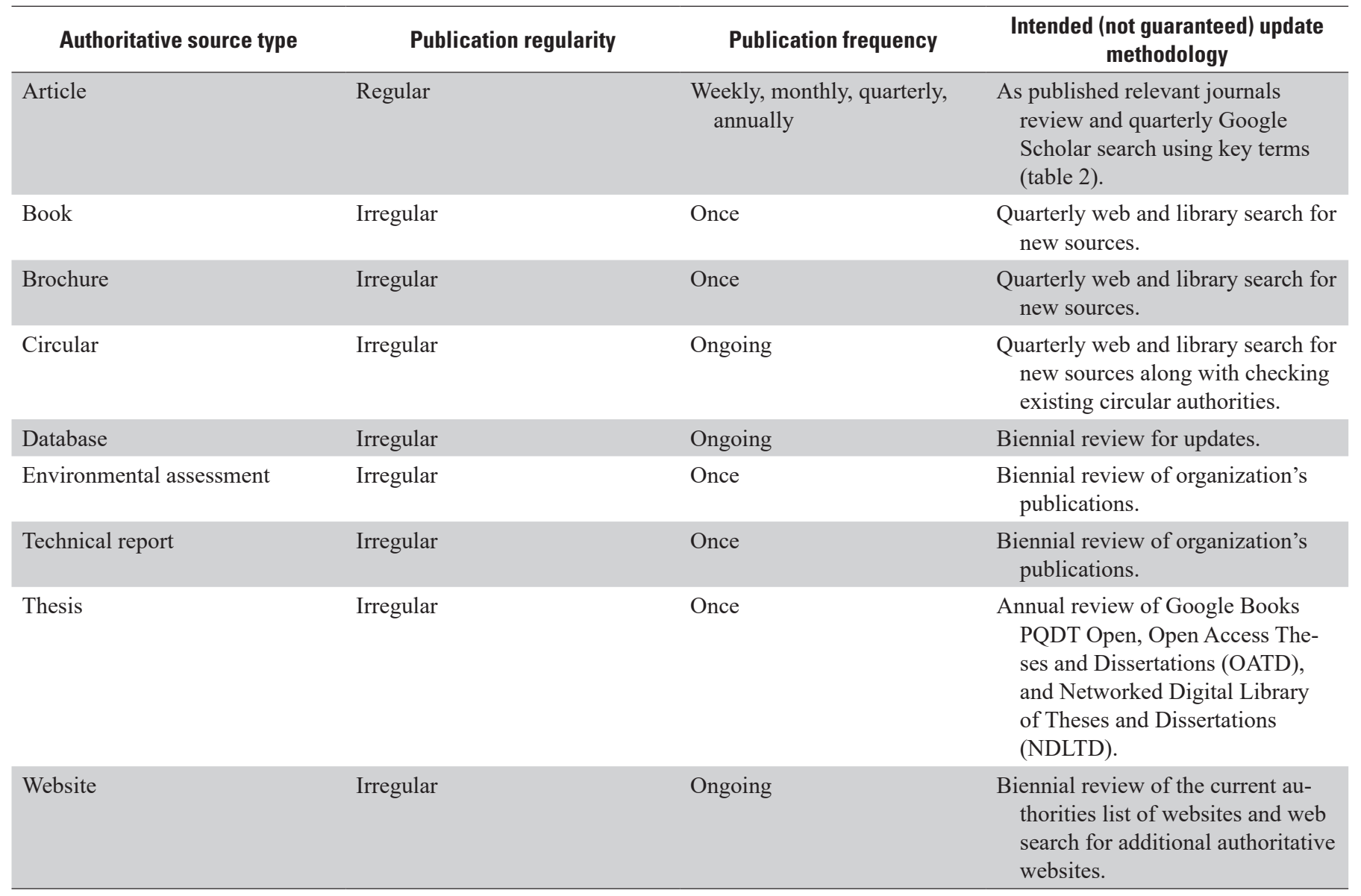

Table 2. Search parameters and terms.

\begin{tabular}{|c|c|}
\hline Parameter & Search terms \\
\hline $\begin{array}{l}\text { Assertion/ } \\
\text { status }\end{array}$ & $\begin{array}{l}\text { Introduced, non-native, invasive, nonindigenous, established, adventive, exotic, alien, immigrant, imported, } \\
\text { first sighting, first occurrence, checklist, feral }\end{array}$ \\
\hline Geographic location & Hawaii, Alaska, United States, U.S., North America, contiguous United States, conterminous United States \\
\hline
\end{tabular}




\section{Criteria for Inclusion}

Creating the non-native species list involved harmonizing large datasets into a common format, standardizing their taxonomy and geographic scope, checking the quality to remove detectable errors and duplicates, and more closely examining outliers. Examples of outliers are names that did not appear in multiple authoritative sources, seemed unlikely to have become established, or were unlikely to be nonnative (for example, with the specific epithet virginiana). For outlier species, multiple authoritative sources were required to justify including the name on the list. Scientific names throughout the non-native species list are most commonly at the species or subspecies/variety level but occasionally at the genus level where the entire genus is non-native. This means taxa that were not identified to the species level (for example, "Hyla spp.") were not included unless it was asserted by an authoritative source that the entire group (most often a genus) is non-native to, and is at some level established in, the area(s) in question (Alaska, Hawaii, or the conterminous United States).

The resulting list of non-native species (Simpson and others, 2018) includes agricultural species (as in domesticated animals, and plants introduced for crops or horticulture) or genetically altered species only if an authoritative source asserted that the taxon has escaped cultivation or captivity and become established in the wild. The names in the non-native species list are not based on the results of species-based searches in the BISON all-taxa mapping application (Jarnevich and others, 2015) but on assertions made by, and compiled from, a growing list of 1,166 other authoritative sources.

\section{Taxonomic Standardization}

Taxonomic synonyms and misspellings were detected and removed from the list using a species lookup tool provided by ITIS, and where appropriate, current taxonomic names and their corresponding Taxonomic Serial Numbers were applied. When current taxonomic names from ITIS were added, original scientific names from sources were retained in the field labeled "providedSciName." Scientific names that were not in ITIS were maintained in the list only if their veracity could be determined from other global or specialized authoritative taxonomic treatments (such as the World Register of Marine Species, 2017; International Committee on Taxonomy of Viruses, 2017; National Center for Biotechnology Information, 2017; and Roskov and others, 2017). Species' common names were obtained (if available) from ITIS, from the authoritative source, or through additional sources obtained during the vetting process.

\section{Invasiveness}

If provided by the listing authoritative source, descriptors regarding the species' invasiveness also were added, including the following terminology: adventive, alien, established, exotic, immigrant, imported, introduced, invasive, non-native, naturalized, and nonindigenous. Because not all authorities defined their terms in the same way and many are described differently by different sources (Richardson and others, 2000; Blackburn and others, 2014), no attempt was made to standardize the invasiveness descriptors.

\section{Regional Criteria}

Although regional species inventories provide valuable contributions to the understanding of invasions (Cadotte and others, 2006), for the purposes of this study, names of species native to anywhere within one of the three defined regions (Alaska, Hawaii, and the conterminous United States) were considered native to that entire region and, therefore, not added to the list. Examples in Alaska are rainbow trout (Oncorhynchus mykiss) and northern pike (Esox lucius), which have each been introduced to Alaskan watersheds where they are not native but do naturally occur elsewhere in the State (Fuller and others, 2013, Fuller and Neilson, 2015). Another example is little duckweed (Lemna obscura), which is native to the conterminous United States but is non-native in Hawaii and is not present in Alaska (U.S. Department of Agriculture, Natural Resources Conservation Service, 2017), meaning that it appears on the list with only a Hawaii designation.

\section{Removal of Nonestablished Taxa}

During the vetting process, it was discovered that occasionally an authoritative source included names in their list of non-native organisms that are not established in the United States and, therefore, do not belong in the non-native species list compiled for this study. This occurred because the taxon had been intercepted and removed (khapra beetle [Trogoderma granarium]; Kavallieratos and others, 2016); it had failed to establish because of insufficient propagule pressure or an inhospitable habitat (red piranha [Pygocentrus nattereri]; Nico and Nielson, 2016); or it was a potential invader known to cause harm elsewhere in similar environmental conditions but not yet established in the United States (Bsal [Batrachochytrium salamandrivorans]; Bales and others, 2015). If a species was suspected to not be established in one of the regions in this study, further literature searches were done; if the searches determined that the species had not been reported as established in the area, the name was moved to an informal watch list to be used to search for possible updates to the list in the future. Watch list names are not included in the total non-native species list counts at this time. 


\section{Protocol for List Updates}

The non-native species list was created by many different scientists consulting hundreds of authoritative sources and is intended (though not guaranteed) to be ongoing; therefore, it was necessary to create a protocol to ensure the list is updated in a consistent manner. Because the effect of differences of opinion among experts is potentially large (McGeoch and others, 2012), criteria for inclusion in this non-native list was created as part of the written protocol. Because of the differences in publication regularity and publication frequency of different authority types, varying temporal and key word approaches to update the list are used, as described in tables 1 and 2.

In addition to the ongoing search regimen outlined above, relevant journal tables of contents such as BioScience, Biological Invasions, Plant Disease, Annals of the Entomological Society of America, Entomological News, Aquatic Invasions, Florida Entomologist, Bishop Museum of Occasional Papers, Proceedings of the Entomological Society of Washington, and Proceedings of the Hawaiian Entomological Society should be reviewed as they are published (Pain, 2016) to help keep the non-native species list current.

Until funding is provided to create a web service allowing the direct submission of invasive species lists by stakeholders, such as that called for by Cardoso and others (2017) for Europe, suggestions for additions to the non-native species list will gratefully be received by the authors (and must include an authoritative source reference).

\section{Use Case-List Comparison with a Species Occurrence Mapping Application}

To test its practical application, the non-native species list was compared with the contents of USGS BISON (Biodiversity Information Serving Our Nation, 2018a). BISON is the largest all-taxa mapping application for the United States and integrates data contained within the globally recognized Global Biodiversity Information Facility and other species occurrence data not available elsewhere. The BISON Solr Application Programming Interface was queried to identify occurrence records for all U.S. non-native species (Biodiversity Information Serving Our Nation, 2018b). A summary of the BISON query results is available in USGS ScienceBase (Simpson and others, 2018; accessible at https://doi.org/10.5066/P9E5K160).

\section{Results of the First Comprehensive List of Non-Native Species Established in Three Major Regions of the United States}

The non-native species list for the three regions of the United States (Alaska, Hawaii, and the conterminous United States) is available for the public to download from USGS ScienceBase (Simpson and others, 2018) at https://doi.org/10.5066/P9E5K160. It consists of a file with four tabs: the non-native species list with complete records for all taxa in each region (13,121 records); the list of 1,166 authoritative sources consulted to create the list; a shorter list of all unique taxa (11,344 names); and a regional taxonomic analysis. This national non-native species list is intended to be regularly updated with new information (including corrections) and be clearly labeled with a version number and release date.

The non-native species list has a total of 11,344 unique taxa (10,652 binominal [species] names or viruses and 74 entire genera). The conterminous United States has the largest number of non-native taxa in the list $(6,675)$, followed by Hawaii $(5,848)$ and Alaska $(598)$. It was unsurprising that the conterminous United States had the largest number of non-native species because it had by far the largest land and water area of 7,898,892 square kilometers $\left(\mathrm{km}^{2}\right)$. However, Hawaii had a larger number than expected based on its much smaller area $\left(28,311 \mathrm{~km}^{2}\right)$, especially when compared to Alaska's 1,704,219 km² (World Atlas, 2016, 2017a, b). Representations of non-native species richness in relation to geographic area are displayed in figures 2-4.
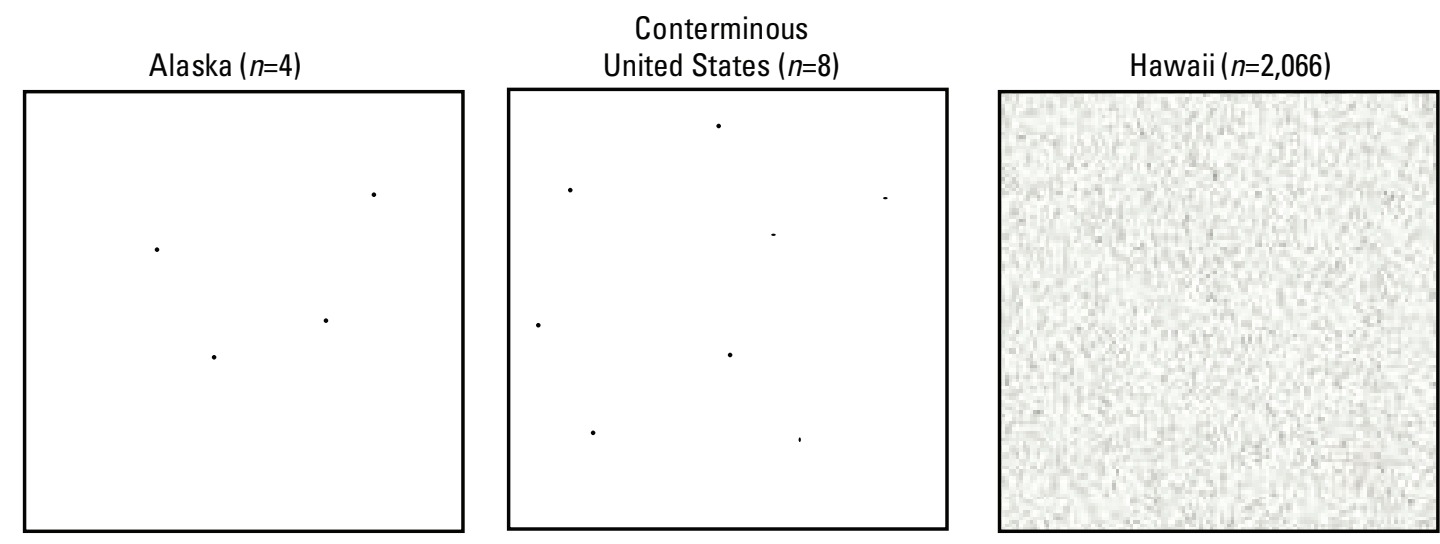

Figure 2. Comparative density of non-native species richness by geographic area (per 10,000 square kilometers, where $n$ is the number of species). 


\section{EXPLANATION}

Number of non-native taxa in the Biodiversity Information Serving Our Nation (BISON) all-taxa mapping application by county

\section{$\geq 1,200$}

1,100 to $<1,200$

1,000 to $<1,100$
900 to $<1,000$

900 to $<1,000$
800 to $<900$

800 to $<900$
700 to $<800$

700 to $<800$
600 to $<700$

600 to $<700$
500 to $<600$

500 to $<600$
400 to $<500$

400 to $<500$
300 to
2400

300 to $<400$

200 to $<300$

$<100$

\section{NORTHWESTERN}

ALASKA

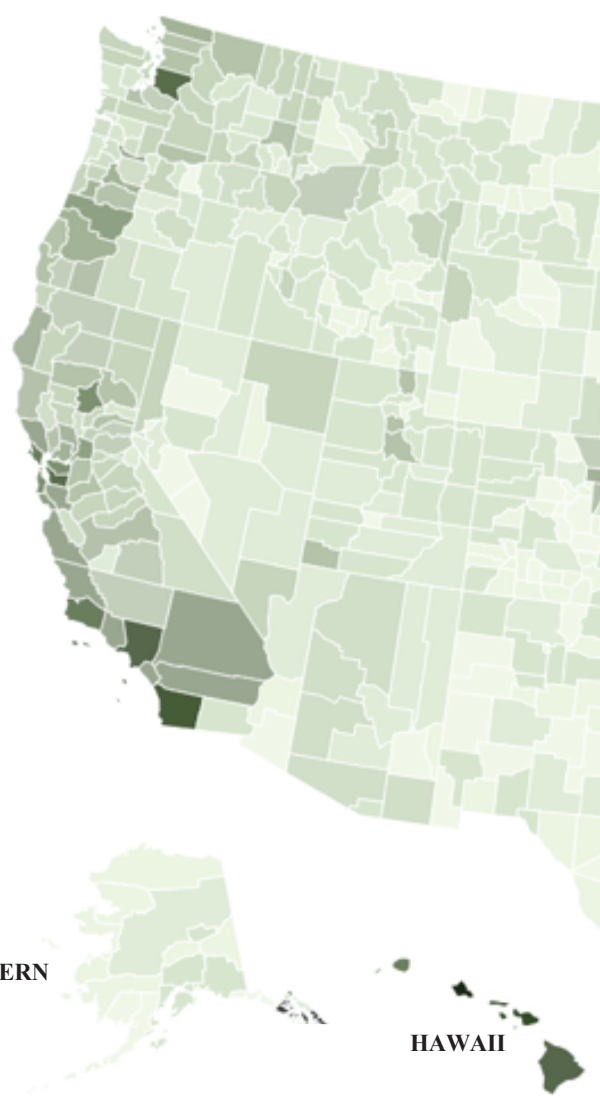

CONTERMINOUS UNITED STATES

Figure 3. Estimated total richness of non-native species (and subspecies) in the United States, by county (data from U.S. Geological Survey [USGS] Biodiversity Information Serving Our Nation [BISON], https://bison.usgs.gov). Because southeastern Alaska recently changed city-borough mapping, the area is not shown. Map created by Gerald F. Guala (USGS). 


\section{EXPLANATION}

Percentage of taxa by county in the Biodiversity Information Serving Our Nation (BISON) all-taxa mapping application that are

\begin{tabular}{|l}
$\geq 33$ \\
30 to $<33$ \\
27 to $<30$ \\
24 to $<27$ \\
21 to $<24$ \\
18 to $<21$ \\
15 to $<18$ \\
12 to $<15$ \\
9 to $<12$ \\
6 to $<9$ \\
3 to $<6$ \\
$<3$
\end{tabular}
non-native

Figure 4. Estimated relative richness of non-native species (and subspecies), as a percentage of total taxa at the county level in the United States (data from U.S. Geological Survey [USGS] Biodiversity Information Serving Our Nation [BISON], https://bison.usgs.gov). Because southeastern Alaska recently changed cityborough mapping, the area is not shown. Map created by Gerald F. Guala (USGS).

CONTERMINOUS UNITED STATES

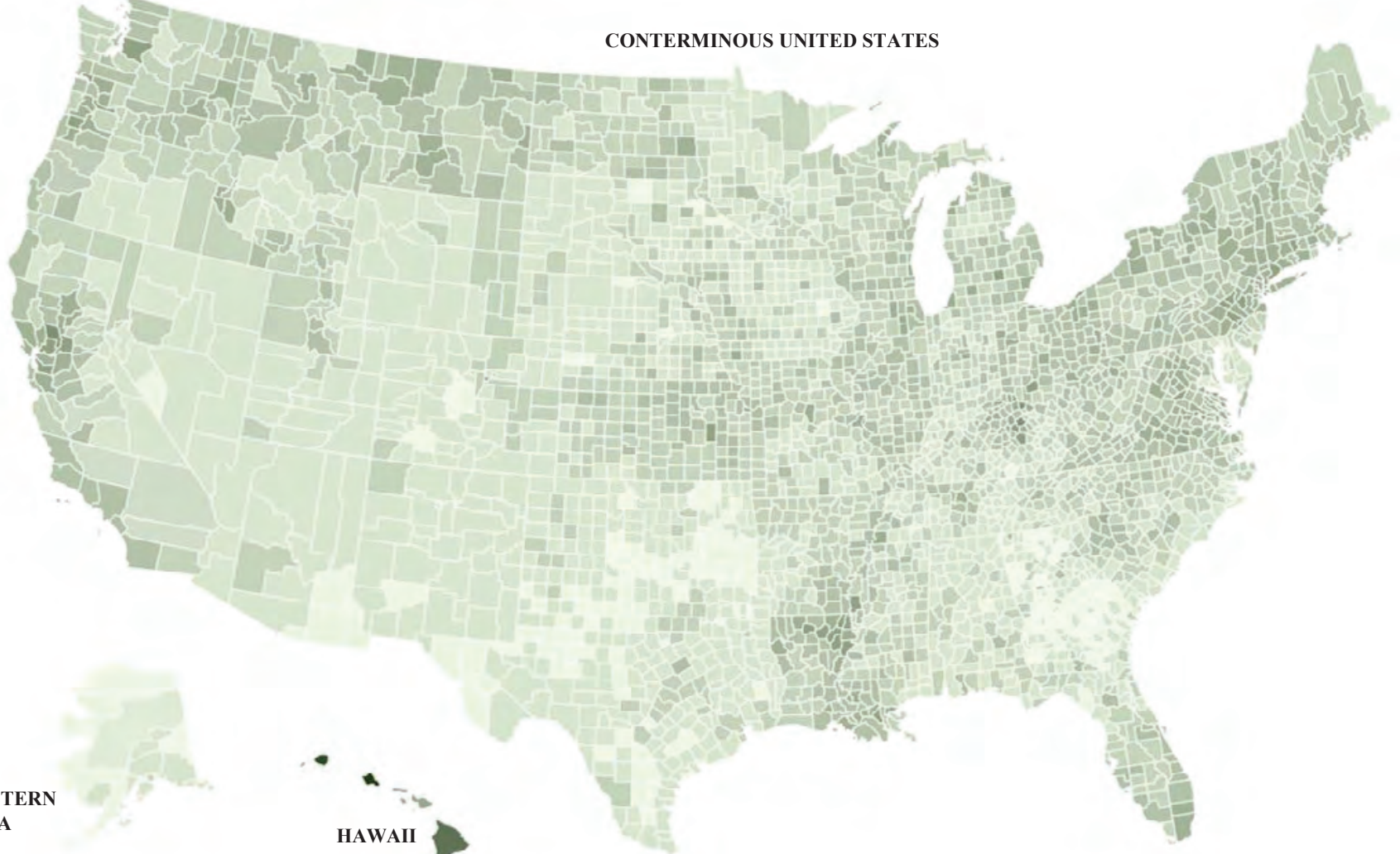


Although the images portray a strong presence of non-native species throughout the United States, non-native species richness and relative non-native species richness must not be confused with non-native species abundance.

The Alaska and conterminous United States non-native species lists were primarily composed of taxa in kingdom Plantae (71.4 and 59.7 percent, respectively), whereas taxa in kingdom Animalia were the second most common (28.1 and 37.8 percent, respectively). The Hawaii non-native species list was the opposite in that the most commonly represented kingdom was Animalia (largely invertebrates; 69.7 percent), and Plantae was the second most commonly represented kingdom (29.8 percent; table 3 ). Viruses are underrepresented in all three regions because (1) assertions of native ranges versus non-native ranges of viruses are scarce and affected by virus host ranges, and (2) the taxonomic classification of viruses has only recently been approached in a systematic way
(Eberhard, 2004). Of the total 11,344 taxa, 157 are established in all 3 regions (Simpson and others, 2018).

As a use case for potential practical applications for the non-native species list, the list was compared to the more than 381 million species occurrence records in BISON. It is important to note that not all species are in BISON and county distributions, while extensive, may not be complete. The BISON search results are available in Simpson and others (2018), accessible at https://doi.org/10.5066/P9E5K160. Species occurrences result from the observation or collection (whole or in part) of a taxon by a person or instrument at a location, date, and time. As of July 2018, the same proportionality of non-native species richness for the three regions also was represented in databased species occurrence records in BISON: 165,284 for Alaska, 474,266 in Hawaii, and 12,810,965 in the conterminous United States (mostly of birds).

Table 3. Kingdom-level taxonomic distributions of the non-native taxa in each region.

\begin{tabular}{|c|c|c|c|c|c|c|}
\hline \multirow[b]{2}{*}{ Kingdom } & \multicolumn{2}{|c|}{ Alaska } & \multicolumn{2}{|c|}{ Hawaii } & \multicolumn{2}{|c|}{ Conterminous United States } \\
\hline & $\begin{array}{c}\text { Number of } \\
\text { taxa }\end{array}$ & $\begin{array}{c}\text { Percentage of } \\
\text { taxa }\end{array}$ & $\begin{array}{c}\text { Number of } \\
\text { taxa }\end{array}$ & $\begin{array}{c}\text { Percentage of } \\
\text { taxa }\end{array}$ & $\begin{array}{c}\text { Number of } \\
\text { taxa }\end{array}$ & $\begin{array}{c}\text { Percentage of } \\
\text { taxa }\end{array}$ \\
\hline Bacteria & 0 & 0.0 & 0 & 0.0 & 13 & 0.2 \\
\hline Chromista & 2 & 0.3 & 6 & 0.1 & 20 & 0.3 \\
\hline Protozoa & 0 & 0.0 & 3 & 0.1 & 8 & 0.1 \\
\hline Virus & 0 & 0.0 & 2 & 0.0 & 8 & 0.1 \\
\hline Total & 598 & 100 & 5,848 & 100 & 6,675 & 100 \\
\hline
\end{tabular}

\section{Discussion}

The creation of a non-native species list for Alaska, Hawaii, and the conterminous United States generated a series of questions that were addressed over the period of this study. The difference in size among the three sublists was substantial, and a use case for the data was explored.

\section{Why are National Non-Native Species Lists Important?}

National species lists are a basic category of information needed to develop an appropriate, evidence-based response to biological invasions (Groom and others, 2017). They serve as important reference points for government efforts to rapidly screen risk and estimate future impact of potentially invasive species (U.S. Fish and Wildlife Service, 2016). The International Plant Protection Convention lists more than 1,000 quarantined plant pests among its 172 member countries (MacLeod and others, 2010). McGeoch and Squires (2015) established a methodology for monitoring and controlling invasive alien species at a global level through a standardized approach to measuring EBVs. They describe the three EBVs for invasion monitoring as follows: (1) species occurrence (is it present and established in the area?); (2) the alien status of a species (is it non-native to the area?); and (3) alien species impact (measuring 10 possible mechanisms, what is its potential impact?). National lists of established non-native species contribute to the calculation of the first two EBVs because lists consist of an assertion of a species' establishment together with the assertion of its alien status in an area and, therefore, are important precursors to measuring national biodiversity and ecosystem health.

A species' establishment and its alien status, when taken together, also substantially contribute to the calculation of impact, where impact is a function of range, per capita effects, and abundance (McGeoch and Squires, 2015). Combining a non-native species list with databased species occurrence data (such as data available through BISON) has been described as a first step in moving toward impact assessment (Parker and others, 1999). Groom and others (2015, p. 119) also asserted 
the importance of recording and rapidly disseminating the occurrence of "newly detected problematic invaders" through national listing mechanisms, including watch lists. With the intent to update this list using an evidence-based methodology and create a web service with easy public access, the goal is that the list will become a national resource for early detection and rapid response.

Habitat loss and introduced species are two of Jared Diamond's "evil quartet" of four main human causes of species' extinctions (Diamond, 1989). Non-native species inventories and lists to inform research analysis and policy development help improve science-based decision making for preventing habitat loss and degradation and helping enhance protections for specific habitat areas (Brodie and others, 2016).

The first and primary EBV for invasion monitoring (Latombe and others, 2017) is creating a national non-native species inventory (or list of established non-native species). However, in that study it was determined that only 11 percent of the 170 Convention on Biological Diversity (CBD) member nations reported having non-native or invasive species lists in 2010. Possibly to assist with this shortcoming, in November 2016, the CBD secretariat announced that the Clearinghouse Mechanism now links within member country profiles to a derived non-native species list that is automatically generated by the Global Invasive Alien Species Information Partnership (Convention on Biological Diversity, 2016). However, the latest update to the partnership database was made in 2013 (Global Invasive Alien Species Information Partnership, 2013).

The completeness of regional species inventories and even the introduction and recording of non-native species could be driven by historical, socioeconomic, or cultural factors. Affluent countries and regions that have directed substantial resources towards creating a more complete record of native species may be the same ones importing and recording more alien species (Dawson and others, 2017).

The relative geographic distribution and ongoing growth of this non-native species list for Alaska, Hawaii, and the conterminous United States, as incomplete as it may be, seems to reinforce three well established premises: that tropical island systems (in this case, Hawaii) are particularly vulnerable to biological invasions (Denslow, 2003; Dawson and others, 2017; Reaser and others, 2007); that higher latitudes (in this case, Alaska) host fewer non-native species but are not invulnerable to future invasions (de Rivera and others, 2011); and that species diversity in general decreases with increasing latitude (Rosenzweig and Sandlin, 1997).

\section{Why are National Non-Native Species Lists Rare?}

Creating species lists is often the first step in a biological inventory of a region. Although a taxonomically targeted inventory may be the preferred method to document rare species, it has been asserted that multiple-species bioblitz surveys (which are short-term intensive efforts that attempt to catalog all taxa in a location) are more likely to produce data on invasive species (Cutko, 2009). In any species listing process, its content is affected by the lists' purpose. Just a few possible types of species lists include the following: comprehensive lists of all species in an area (products of biological inventories or bioblitzes), lists of species of concern (threatened or endangered), specialized lists of useful or medicinal species or those attractive to pollinators (which may contain non-native species), lists of species of negative effect (native pest and invasive species), and watch lists of nonnative species (species found in surrounding areas or in similar habitats that could pose a threat but are not established in the area in question). The diverse nature of non-native and other species lists made the comparative compilation of this report's list more challenging.

Subnational lists and inventories are much more common than national ones. For example, many States in the United States maintain their own noxious weed lists (that may or may not include native species or watch list species not yet established), and land managers in individual protected areas make lists based on local inventories. All-taxa and smaller taxonomic group inventories for Hawaii have been created and updated periodically by the Bishop Museum (for example, Eldredge and Evenhuis, 2003; Staples and Imada, 2006), and an attempt was made in those publications to distinguish between endemic (native) and non-native species numbers for most groups but without listing non-native species names. In another regional example, a composite list of marine invaders along the Pacific coast of the United States was used to determine factors that affect biological invasions through the broad characterization of their temporal and spatial contexts (Ruiz and others, 2011). Other kinds of non-native species lists that are more common than comprehensive national level lists are those with a relatively narrow taxonomic scope (Aukema and McCullough, 2009), which may be prepared to address a specific research question such as determining economic impact of the taxonomic group on a specific resource or ecosystem (Aukema and others, 2011).

\section{National Lists of Non-Native Species- A Use Case}

BISON has more than 381 million native and non-native species occurrence records as of February 2018. It includes records for 427,123 different taxa from 2,124 datasets. It is an integrated resource for biological occurrence data from the United States and Canada that uses ITIS as its taxonomic backbone for species lookup. Because the scope of USGS BISON is all taxa, it contains significantly more species occurrences for the United States than the largest invasive species database, the Early Detection and Distribution Mapping System (EDDMapS; Wallace and Bargeron, 2014), which contained 4.4 million species occurrences as of June 2018. 


\section{Exposing Non-Native Species Occurrences}

Most species occurrence records available through USGS BISON for non-native taxa are not labeled as such within the record by data owners (for example, when compiled by citizen scientists for datasets such as eBird or included in many museum collections). To expose these untagged non-native species records, the non-native species list was compared with BISON; as of July 2018, BISON contained $13,450,515$ occurrence records for non-native taxa, including records for 77 percent of the Alaska non-native species sublist, 75 percent of the conterminous United States sublist, and 37 percent of the Hawaii sublist (Simpson and others, 2018). The non-native species list can be used to search any U.S. species occurrence database to potentially expose even more invasive species occurrence data that may not be recognized or tagged as non-native. These data could then be integrated into invasive species databases (such as EDDMapS and others) to fill in geographic and taxonomic gaps in invasive species data coverage for the United States.

Looking up the non-native species names provided in the list within species mapping applications (and data integrators) such as BISON provides a strong use case for non-native species lists. The list makes an assertion of non-native status, and the databased species occurrence records validate the list, while also exposing gaps in geographic coverage (areas that have not yet been surveyed) or data availability (areas where data may exist but are not published or available electronically or in other forms) and providing an indication of non-native species richness and occurrence. The species occurrence data available for all taxa through the BISON application can be mined and used to inform important management decisions and invasive species policy.

The non-native species list has now been used by the BISON project to tag species occurrence records, where applicable, as non-native in Alaska, Hawaii, and the conterminous United States, even where this information was not included in the species occurrence records by the data providers themselves. As a result, decision makers can now draw on millions more non-native species occurrence records than were previously available.

\section{Exposing Taxonomic and Geographic Gaps}

As pointed out in the previous section, across the three regions, only 37 percent of the species on the Hawaii sublist are represented by occurrence records in BISON. These results have provided the BISON project with an incentive to pursue additional species occurrence datasets for Hawaii and for datasets that include records for underrepresented taxa. The BISON project also hopes to eventually provide the non-native species list as a web service (through the BISON application) to further facilitate free sharing of non-native species data.

\section{Indicators of Non-Native Species Richness}

With the results of the BISON search, the number of non-native taxa at the county level was mapped (fig. 3), and species richness varies widely throughout the country. Figure 4 displays the proportion of non-native to native species in BISON, showing higher percentages (more than 33 percent in Hawaii) are generally evident in coastal areas and other regional hotspots. Additional data are needed to perform a more in-depth analysis of non-native species richness and abundance.

\section{Most Pervasive Species}

Although control efforts have contained some of the most pervasive non-native species at local levels (for example, pigeons, thistles, and rodents), because of their sheer numbers many are no longer federally regulated species. Pheasants (Phasianus colchicus) and partridges (Alectoris chukar) are raised for hunting, and European honeybees (Apis mellifera) are imported and managed for pollinating crops, indicating that some managed and escaped non-native species may be beneficial to humans. Widespread and expensive control efforts on cheatgrass (downy brome, Bromus tectorum) and house mice (Mus musculus) are ongoing because of the extensive economic and environmental damage they cause (Witmer and Moulton, 2014; U.S. Forest Service, 2014). Some of the most common non-native taxa also are the earliest recorded species introduced in the United States. For example, European honeybees were introduced in the 1620s (Crane, 1999); the common pigeon (Columba livia) is the world's oldest known domesticated bird and also was introduced into the United States in the 1600s (Schorger, 1952); the house sparrow (Passer domesticus) was introduced in New York in 1851 (Moulton and others, 2010); and tree of heaven (Ailanthus altissima) was introduced in the late 1700s (Fryer, 2010).

Of the 157 taxa with the broadest distribution and occurrence in BISON, established across all three regions (Simpson and others, 2018), vascular plants are the most numerous (125, with grasses and asters leading the list), followed by arthropods (13), mammals (11), birds (6), mollusks (3), and bryozoans (1). Species occurrence also is a function of observers' ability to spot and identify taxa, so larger, more charismatic species will generally be more abundant within species occurrence databases.

\section{National Lists of Non-Native Species-Caveats}

Although effort was made to expand the non-native species list to include invertebrates and microbes, the results must be considered incomplete because species are still being discovered (Costello and others, 2013); noncharismatic and difficult-to-identify species tend to be overlooked (Brodie and others, 2016); and the species composition of any nation in this era of globalization is constantly subject to change (Meyerson and Mooney, 2007). 


\section{Summary and Conclusions}

The first comprehensive list of non-native species established in the United States consists of 11,344 unique taxa that have become established in Alaska, Hawaii, the conterminous United States, or a combination of these regions, and the list is still growing as more species are discovered or become established within the country. There are 157 taxa established in all 3 regions. As of July 26, $2018,1,166$ authoritative sources have been consulted to generate the list.

The relative geographic distribution and ongoing growth of this non-native species list for Alaska, Hawaii, and the conterminous United States, as incomplete as it may be, seems to reinforce three well established premises: that tropical island systems (in this case, Hawaii) are particularly vulnerable to biological invasions; that higher latitudes (in this case, Alaska) host fewer non-native species but are not invulnerable to future invasions; and that species diversity in general decreases with increasing latitude.

Because it was compiled by various researchers from regional U.S. Geological Survey science centers over a period of 6 years, a protocol for species inclusion and for ongoing updates was created and continues to be followed. The Integrated Taxonomic Information System provides the taxonomic framework for the names in the list, but scientific names provided by the authoritative sources are also retained. Viruses are included in the list but are underrepresented in all three regions because assertions of native ranges versus non-native ranges of viruses are scarce, and the taxonomic classification of viruses has only recently been approached in a systematic way. The diverse nature of non-native and other species lists made the comparative compilation of this report's list more challenging, and it was found that subnational lists and inventories are much more common than national ones.

Although the compilation of a comprehensive non-native species list at the national level is especially daunting for the United States because of its size and other factors described herein, its potential uses are broad, and some possible applications of this list are discussed here. Uses for the list include contributing to the measurement of Essential Biodiversity Variables for invasive species monitoring, measuring gaps in coverage within species occurrence databases, providing geographic reference points for early detection and rapid response, and assisting with prioritizing species' potential impacts.

The non-native species list was also used to search for non-native species occurrence records in Biodiversity Information Serving Our Nation (BISON), an all-taxa mapping application that has more than 381 million native and non-native species occurrence records (as of February 2018). Through the process of tagging non-native taxa represented by occurrence records in USGS BISON, it was found that BISON contains $13,450,515$ occurrence records for non-native taxa, many of which were not labeled as non-native by the original data providers of the records.
Work on maintaining the non-native species list is currently ongoing. The intent, though not a guarantee, is that this national non-native species list will be continually and regularly updated with new information (including corrections), made publicly available online and in a machinereadable web service format, and be clearly labeled with a version number and release date.

\section{References Cited}

Ache, B., 2002, Gulf of Mexico regional panel on aquatic nuisance species annual report 2001-An initial survey of aquatic invasive species issues in the Gulf of Mexico region: EPA 855-R-02-003, U.S. Environmental Protection Agency technical report 200514, $28 \mathrm{p}$.

Aukema, J.E., and McCullough, D., 2009, Non-native forest insects and pathogens in the continental US: The Knowledge Network for Biocomplexity, accessed July 11, 2017, at https://knb.ecoinformatics.org/\#view/doi:10.5063/AA/ nuding.7.9.

Aukema, J.E., Leung, B., Kovacs, K., Chivers, C., Britton, K.O., Englin, J., Frankel, S.J., Haight, R.G., Holmes, T.P., Liebhold, A.M., McCullough, D.G., and Von Holle, B., 2011, Economic impacts of non-native forest insects in the continental United States: PLoS ONE, v. 6, no. 9, art. e24587, accessed July 11, 2017, at https://doi.org/10.1371/journal.pone.0024587.

Bales, E.K., Hyman, O.J., Loudon, A.H., Harris, R.N., Lipps, G., Chapman, E., Roblee, K., Kleopfer, J.D., and Terrell, K.A., 2015, Pathogenic chytrid fungus Batrachochytrium dendrobatidis, but not $B$. salamandrivorans, detected on Eastern hellbenders: PLoS One, v. 10, no. 2, art. e0116405, accessed July 11, 2018, at https://doi.org/10.1371/journal.pone.0116405.

Biodiversity Information Serving Our Nation, 2018a, Biodiversity Information Serving Our Nation all-taxa mapping application: U.S. Geological Survey, accessed October 4, 2018, at https://bison.usgs.gov.

Biodiversity Information Serving Our Nation, 2018b, Solr Application Programming Interface, U.S. Geological Survey, sample query accessed October 3, 2018, at https://bison.usgs.gov/solr/occurrences/select/?q=comput edCountyFips:06071\%20AND\%20ITISscientificName:/ [A-Za-z0-9]*[\%20]\{1,1\}[A-Za-z0-9]*[\%20]\{0,1\}[A-Za-z09]*/\%20AND\%20establishmentMeans:L48\&facet=true\&f acet.field $=$ ITISscientificName \& facet.limit=-1\&facet.mincoun $\mathrm{t}=1$ \&rows $=0 \& \mathrm{wt}=\mathrm{json} \&$ indent $=$ true. 
Blackburn, T.M., Essl, F., Evans, T., Hulme, P.E., Jeschke, J.M., Kühn, I., Kumschick, S., Markovà, Z., Mrugała, A., Nentwig, W., Pergl, P., Pyšek, P., Rabitsch, W., Ricciardi, A., Richardson, D.M., Sendek, A., Vilà, M., Wilson, J.R.U., Winter, M., Genovesi, P., and Bacher, S., 2014, A unified classification of alien species based on the magnitude of their environmental impacts: PLoS Biology, v. 12, no. 5, art. E1001850, accessed July 12, 2017, at https://doi.org/10.1371/journal.pbio.1001850.

Brodie, G., Miller, C., Pippard, H., and Kami, T., 2016, Species conservation in the Pacific Islands-Taking effective steps forward: Pacific Conservation Biology, v. 22, no. 3, p. 201-202, accessed November 15, 2017, at https://doi.org/ 10.1071/PCv22n3_ED.

Cadotte, M.W., Murray, B.R., and Lovett-Doust, J., 2006, Ecological patterns and biological invasions-Using regional species inventories in macroecology: Biological Invasions, v. 8, no. 4, p. 809-821, accessed July 3, 2017, at https://doi.org/10.1007/s10530-005-3839-4.

Cardoso, A.C., Tsiamis, K., Gervasini, E., Schade, S., Taucer, F., Adriaens, T., Copas, K., Flevaris, S., Galiay, P., Jennings, E., Josefsson, M., López, B.C., Magan, J., Marchante, E., Montani, E., Roy, H., von Schomberg, R., See, L., and Quintas, M., 2017, Citizen science and open data-A model for Invasive Alien Species in Europe: Research Ideas and Outcomes, v. 3, p. 1-20, accessed July 12, 2017, at https://doi.org/10.3897/rio.3.e14811.

Convention on Biological Diversity, 2016, Data on Invasive Alien Species available on the Clearing-House Mechanism of the Convention on Biological Diversity: Montreal, Quebec, Canada, United Nations Environment Programme, Secretariat of the Convention on Biological Diversity, SCBD/SPS/CG/JSH/86109, accessed June 19, 2018, at https://www.cbd.int/doc/notifications/2016/ ntf-2016-142-ias-en.doc.

Costello, M.J., May, R.M., and Stork, N.E., 2013, Can we name Earth's species before they go extinct?: Science, v. 339 , no. 6118 , p. 413-416, accessed July 6, 2017, at https://doi.org/10.1126/science.1230318.

Crane, E., 1999, The world history of beekeeping and honey hunting: New York, Routledge, p. 359.

Cutko, A., 2009, Biodiversity inventory of natural lands-A how-to manual for foresters and biologists: Arlington, Va., NatureServe, accessed July 6, 2017, at http:/www.natureserve.org/sites/default/files/publications/ biodiversityinventorymanual_main.pdf.
Dawson, W., Moser, D., van Kleunen, M., Kreft, H., Pergl, J., Pyšek, P., Weigelt, P., Winter, M., Lenzner, B., Blackburn, T.M., Dyer, E.E., Cassey, P., Scrivens, S.L., Economo, E.P., Guénard, B., Capinha, C., Seebens, H., García-Díaz, P., Nentwig, W., García-Berthou, E., Casal, C., Mandrak, N.E., Fuller, P., Meyer, C., and Essl, F., 2017, Global hotspots and correlates of alien species richness across taxonomic groups: Nature Ecology \& Evolution, v. 1, art. 0186, accessed July 10, 2017, at https://doi.org/10.1038/s41559-017-0186.

de Rivera, C., Steves, B.P., Fofonoff, P.W., Hines, A.H., and Ruiz, G.M., 2011, Potential for high-latitude marine invasions along western North America: Diversity and Distributions, v. 17, no. 6, p. 1198-1209, accessed July 10, 2017, at https://doi.org/10.1111/j.1472-4642.2011.00790.x.

Denslow, J.S., 2003, Weeds in paradise-Thoughts on the invasibility of tropical islands: Annals of the Missouri Botanical Garden, v. 90, no. 1, p. 119-127, accessed July 6, 2017, at https://doi.org/10.2307/3298531.

Diamond, J.M., 1989, Overview of recent extinctions, in Western, D., and Pearl, M.C., eds., Conservation for the twenty-first century: London, United Kingdom, Oxford University Press, p. 37-41.

Eberhard, M.L., 2004, Virus taxonomy-One step forward, two steps back: Emerging Infectious Diseases, v. 10, no. 1, p. 153-154, accessed October 31, 2017, at https://doi.org/10.3201/eid1001.030945.

Eldredge, L.G., and Evenhuis, N.L., 2003, Hawaii's biodiversity - A detailed assessment of the numbers of species in the Hawaiian Islands: Bishop Museum Occasional Papers, no. 76, 30 p., accessed July 10, 2017, at http://hbs.bishopmuseum.org/pubs-online/pdf/op76.pdf.

Executive Office of the President, 2016, Executive Order 13751-Safeguarding the Nation from the impacts of invasive species: Federal Register, v. 81, no. 236, p. 88609-88614, accessed July 31,2017 , at https://www.gpo.gov/fdsys/pkg/FR-2016-12-08/ pdf/2016-29519.pdf.

Fryer, J.L., 2010, Ailanthus altissima, in Fire Effects Information System: U.S. Department of Agriculture, Forest Service, Rocky Mountain Research Station, Fire Sciences Laboratory, accessed July 27, 2018, at https://www.fs.fed.us/database/ feis/plants/tree/ailalt/all.html.

Fuller, P., Larson, J., Fusaro, A., Makled, T.H., and Neilson, M., 2013, Oncorhynchus mykiss (Walbaum, 1792): Gainesville, Fla., U.S. Geological Survey, Nonindigenous Aquatic Species Database, accessed on July 19, 2017, at https://nas.er.usgs.gov/ queries/FactSheet.aspx?SpeciesID $=910$. 
Fuller, P., and Neilson, M., 2015, Esox lucius Linnaeus, 1758: Gainesville, Fla., U.S. Geological Survey, Nonindigenous Aquatic Species Database, accessed on August 28, 2017, at https://nas.er.usgs.gov/queries/ FactSheet.aspx?SpeciesID $=676$.

Global Invasive Alien Species Information Partnership, 2013, Revisions for using the site: Global Invasive Alien Species Information Partnership Gateway, accessed on June 19, 2018, at http:/giasipartnership.myspecies.info/en/content/ using-site\#overlay=en/node/18291/revisions.

Groom, Q.J., Desmet, P., Vanderhoeven, S., and Adriaens, T., 2015, The importance of open data for invasive alien species research, policy and management: Management of Biological Invasions, v. 6, no. 2, p. 119-125, accessed July 11, 2017, at https://doi.org/10.3391/mbi.2015.6.2.02.

Groom, Q.J., Adriaens, T., Desmet, P., Simpson, A., De Wever, A., Bazos, I., Cardoso, A.C., Charles, L., Christopoulou, A., Gazda, A., Helmisaari, H., Hobern, D., Josefsson, M., Lucy, F., Marisavljevic, D., Oszako, T., Pergl, J., Petrovic-Obradovic, O., Prévot, C., Ravn, H.P., Richards, G., Roques, A., Roy, H.E., Rozenberg, M.A., Scalera, R., Tricarico, E., Trichkova, T., Vercayie, D., Zenetos, A., and Vanderhoeven, S.,2017, Seven recommendations to make your invasive alien species data more useful: Frontiers in Applied Mathematics and Statistics, v. 3, 13 p., accessed October 1, 2017, at https://doi.org/10.3389/fams.2017.00013.

Hulme, P.E., Pyšek, P., Nentwig, W., and Vilà, M., 2009, Will threat of biological invasions unite the European Union?: Science, v. 324, no. 5923, p. 40-41, accessed July 16, 2018, at https://doi.org/10.1126/science.1171111.

International Committee on Taxonomy of Viruses, 2017, Taxonomic information: International Committee on Taxonomy of Viruses, accessed on July 6, 2017, at https://talk.ictvonline.org/taxonomy/.

Integrated Taxonomic Information System, 2017, The Integrated Taxonomic Information System: Integrated Taxonomic Information System Database, accessed on July 6, 2017, at https://www.itis.gov.

Jarnevich, C.S., Simpson, A., Graham, J.J., Newman, G.J., and Bargeron, C.T., 2015, Running a network on a shoestring-The Global Invasive Species Information Network: Management of Biological Invasions, v. 6, no. 2, p. 137-146, accessed August 8, 2018, at https://doi.org/10.3391/ mbi.2015.6.2.04.

Kavallieratos, N.G., Athanassioub, C.G., Bardaa, M.S., and Boukouvalaac, M.C., 2016, Efficacy of five insecticides for the control of Trogoderma granarium Everts (Coleoptera: Dermestidae) larvae on concrete: Journal of Stored Products Research, v. 66, p. 18-24, accessed on July 10, 2018, at https://doi.org/10.1016/j.jspr.2015.12.001.
Kissling, W.D., Ahumada, J.A., Bowser, A., Fernandez, M., Fernández, N., García, E.A., Guralnick, R.P., Isaac, N.J.B., Kelling, S., Los, W., McRae, L., Mihoub, J.B., Obst, M., Santamaria, M., Skidmore, A.K., Williams, K.J., Agosti, D., Amariles, D., Arvanitidis, C., Bastin, L., De Leo, F., Egloff, W., Elith, J., Hobern, D., Martin, D., Pereira, H.M., Pesole, G., Peterseil, J., Saarenmaa, H., Schigel, D., Schmeller, D.S., Segata, N., Turak, E., Uhlir, P.F., Wee, B., and Hardisty, A.R., 2017, Building essential biodiversity variables (EBVs) of species distribution and abundance at a global scale: Biological Reviews, v. 93, no. 1, p. 600-625, accessed August 8, 2017, at https://doi.org/10.1111/brv.12359.

Latombe, G., Pyšek, P., Jeschke, J.M., Blackburn, T.M., Bacher, S., Capinha, C., Costello, M.J., Fernández, M., Gregory, R.D., Hobern, D., Hui, C., Jetz, W., Kumschick, S., McGrannachan, C., Pergl, J., Roy, H.E., Scalera, R., Squires, Z.E., Wilson, J.R.U., Winter, M., Genovesi, P., and McGeoch, M.A., 2017, A vision for global monitoring of biological invasions: Biological Conservation, v. 213, pt. B, p. 295-308, accessed November 1, 2017, at https://doi.org/10.1016/j.biocon.2016.06.013.

MacLeod, A., Pautasso, M., Jeger, M.J., and Haines-Young, R., 2010, Evolution of the international regulation of plant pests and challenges for future plant health: Food Security, v. 2, no. 1, p. 49-70, accessed July 12, 2017, at https://doi.org/10.1007/s12571-010-0054-7.

McGeoch, M.A., Spear, D., Kleynhans, E.J., and Marais, E., 2012, Uncertainty in invasive alien species listing: Ecological Applications, v. 22, no. 3, p. 959-971, accessed November 1, 2017, at https://doi.org/10.1890/11-1252.1.

McGeoch, M.A., and Squires, Z.E., 2015, An essential biodiversity variable approach to monitoring biological invasions - Guide for countries: GEO BON Technical Series 2, 13 p., accessed July 3, 2017, at http://invasionevs.com/ wp-content/uploads/2015/08/MonitoringBiologicalInvasions. TechnicalReport.pdf.

Meyerson, L.A., and Mooney, H.A., 2007, Invasive alien species in an era of globalization: Frontiers in Ecology and the Environment, v. 5, no. 4, p. 199-208, accessed July 10, 2017, at https://doi.org/10.1890/ 1540-9295(2007)5[199:IASIAE]2.0.CO;2.

Moulton, M.P., Cropper, W.P., Jr., Avery, M.L., and Moulton, L.E., 2010, The earliest house sparrow introductions to North America: U.S. Department of Agriculture, National Wildlife Research Center, Staff Publications, no. 961, accessed July 27, 2018, at https://digitalcommons.unl.edu/ icwdm_usdanwrc/961.

National Center for Biotechnology Information, 2017, Taxonomy: U.S. National Library of Medicine, National Center for Biotechnology Information, Taxonomy Database, accessed on July 6, 2017, https://www.ncbi.nlm.nih.gov/ taxonomy. 
Nico, L., and Neilson, M., 2016, Pygocentrus nattereri Kner, 1858: Gainesville, Fla., U.S. Geological Survey, Nonindigenous Aquatic Species Database, accessed July 10, 2018, at https://nas.er.usgs.gov/queries/ FactSheet.aspx?SpeciesID=429.

Olenin, S., and Didžiulis, V., 2009, Introduction to the List of Alien Taxa, in Nentwig, W., ed., Handbook of Alien Species in Europe-Invading Nature, Springer Series in Invasion Ecology v. 3: Dordrecht, Springer, https://doi.org/10.1007/978-1-4020-8280-1_10.

Pain, E., 2016, How to keep up with the scientific literature: Science Magazine, accessed on July 2, 2018, at https://doi.org/10.1126/science.caredit.a1600159.

Parker, I.M., Simberloff, D., Lonsdale, W.M., Goodell, K., Wonham, M., Kareiva, P.M., Williamson, M.H., Von Holle, B., Moyle, P.B., Byers, J.E., and Goldwasser, L., 1999, Impact-Toward a framework for understanding the ecological effects of invaders: Biological Invasions, v. 1, no. 1, p. 3-19, accessed November 1, 2017, at https://doi.org/10.1023/A:1010034312781.

Pereira, H.M., Ferrier, S., Walters, M., Geller, G.N., Jongman, R.H.G., Scholes, R.J., Bruford, M.W., Brummitt, N., Butchart, S.H.M., Cardoso, A.C., Coops, N.C., Dulloo, E., Faith, D.P., Freyhof, J., Gregory, R.D., Heip, C., Höft, R., Hurtt, G., Jetz, W., Karp, D.S., McGeoch, M.A., Obura, D., Onoda, U., Pettorelli, N., Reyers, B., Sayre, R., Scharlemann, J.P.W., Stuart, S.N., Turak, E., Walpole, M., and Wegmann, M., 2013, Essential biodiversity variables: Science, v. 339, no. 6117 , p. 277-278, accessed June 11, 2018, at https://doi.org/10.1126/science.1229931.

Reaser, J.K., Meyerson, L.A., Cronk, Q., de Poorter, M., Eldredge, L.G., Green, E., Kairo, M., Latasi, P., Mack, R.N., Mauremootoo, J., O'Dowd, D., Orapa, W., Sastroutomo, S., Saunders, A., Shine, C., Thrainsson, S., and Vaiutu, L., 2007, Ecological and socioeconomic impacts of invasive alien species in island ecosystems: Environmental Conservation, v. 34 , no. 2, p. 98-111, accessed July 10, 2017, at https://doi.org/10.1017/S0376892907003815.

Richardson, D.M., Pyšek, P., Rejmánek, M., Barbour, M.G., Panetta, F.D., and West, C.J., 2000, Naturalization and invasion of alien plants-Concepts and definitions: Diversity and Distributions, v. 6, no. 2, p. 93-107, accessed July 6, 2017, at https://doi.org/10.1046/j.1472-4642.2000.00083.x.

Rosenzweig, M.L., and Sandlin, E.A., 1997, Species diversity and latitudes - Listening to area's signal: Oikos, v. 80, no. 1, p. 172-176, accessed July 6, 2017, at https://doi.org/10.2307/3546528.
Roskov, Y., Abucay, L., Orrell, T., Nicolson, D., Bailly, N., Kirk, P.M., Bourgoin, T., DeWalt, R.E., Decock, W., De Wever, A.,van Nieukerken, E., Zarucchi, J., and Penev, L., eds., 2017, Species 2000 \& ITIS Catalogue of Life, 2017 annual checklist: Leiden, the Netherlands, Naturalis, accessed July 6, 2017, at http://www.catalogueoflife.org/annual-checklist/2017.

Ruiz, G.M., Fofonoff, P.W., Steves, B., Foss, S.F., and Shiba, S.N., 2011, Marine invasion history and vector analysis of California-A hotspot for western North America: Diversity and Distributions, v. 17, no. 2, p. 362-373, accessed October 11, 2017, at https://doi.org/10.1111/ j.1472-4642.2011.00742.x.

Schorger, A.W., 1952, Introduction of the domestic pigeon: The Auk, v. 69, no. 4, p. 462-463, accessed August 15, 2018, at https://doi.org/10.2307/4081033.

Simpson, A., Eyler, M.C., Cannister, M., Libby, R., Kozlowski, N., Sellers, E., and Guala, G.F., 2018, Dataset of the first comprehensive list of non-native species established in three major regions of the United States: U.S. Geological Survey data release, https://doi.org/10.5066/P9E5K160.

Simpson, A., Mannas, M., and Sellers, E., 2018, Authoritative lists of non-native species for AK, HI, L48-A data management plan created using DMPTool: U.S. Geological Survey, 14 p., accessed September 15, 2018, at https://doi.org/10.5066/P9E5K160.

Staples, G.W., and Imada, C.T., 2006, Checklist of Hawaiian anthocerotes and hepatics: Tropical Bryology, v. 28, p. 15-47, accessed June 19, 2018, at http://hbs.bishopmuseum.org/ pdf/5-staples.pdf.

Sutherland, W.J., Pullin, A.S., Dolman, P.M., and Knight, T.M., 2004, The need for evidence-based conservation: Trends in Ecology \& Evolution, v. 19, no. 6, p. 305-308, accessed July 17, 2017, at https://doi.org/10.1016/ j.tree.2004.03.018.

U.S. Department of Agriculture, Natural Resources Conservation Service, 2017, The PLANTS Database: Greensboro, N.C., National Plant Data Team, accessed August 8, 2017, at https://plants.usda.gov.

U.S. Department of the Interior, 2016, Safeguarding America's lands and waters from invasive species-A national framework for early detection and rapid response: Washington D.C., U.S. Department of the Interior, 55 p., accessed on June 30, 2017, at https://www.doi.gov/sites/doi. gov/files/National\%20EDRR\%20Framework.pdf.

U.S. Fish and Wildlife Service, 2016, Standard operating procedures for the rapid screening of species' risk of establishment and impact in the United States: U.S. Fish and Wildlife Service, accessed on November 15, 2017, at https://www.fws.gov/injuriouswildlife/pdf_files/ERSS-SOPFinal-Version.pdf. 
U.S. Forest Service, 2014, Field guide for managing cheatgrass in the Southwest: U.S. Forest Service, Southwestern Region, TP-R3-16-04, accessed November 13, 2017, at https://www.fs.usda.gov/Internet/FSE_DOCUMENTS/ stelprdb5410110.pdf.

Wallace, R.D., and Bargeron, C.T., 2014, Identifying invasive species in real time-Early detection and distribution mapping system (EDDMapS) and other mapping tools, chap. 13 of Ziska, L.H., and Dukes, J.S., eds., Invasive species and global climate change: CABI Invasive Series, v. 4, p. 219-231.

Witmer, G.W., and Moulton, R.S., 2014, Improving invasive house mice control and eradication strategies via more effective rodenticides: University of California, U.S. Department of Agriculture, National Wildlife Research Center, Staff Publications, p. 67-72, accessed November 13, 2017, at http://digitalcommons.unl.edu/ icwdm_usdanwre/1786/.
World Atlas, 2016, Geographic statistics of the United States of America: World Atlas, accessed on July 12, 2017, at https://www.worldatlas.com/webimage/countrys/namerica/ usstates/uslandst.htm\#page.

World Atlas, 2017a, Alaska - Geographic statistics: World Atlas, accessed on July 6, 2017, at https://www.worldatlas.com/ webimage/countrys/namerica/usstates/aklandst.htm\#page.

World Atlas, 2017b, Hawaii - Geographic statistics: World Atlas, accessed on July 6, 2017, at https://www.worldatlas.com/ webimage/countrys/namerica/usstates/hilandst.htm\#page.

World Register of Marine Species, 2017, WoRMS Taxon match: World Register of Marine Species, accessed on July 6, 2017, at http://www.marinespecies.org/ aphia.php? $\mathrm{p}=$ match. 
For more information about this publication, contact:

Director, USGS Science Analytics and Synthesis Program

West 6th Avenue and Kipling Street

Lakewood, CO 80225

303-202-4774

csas@usgs.gov

For additional information visit

https://www.usgs.gov/science/mission-areas/core-sciencesystems/csasl 



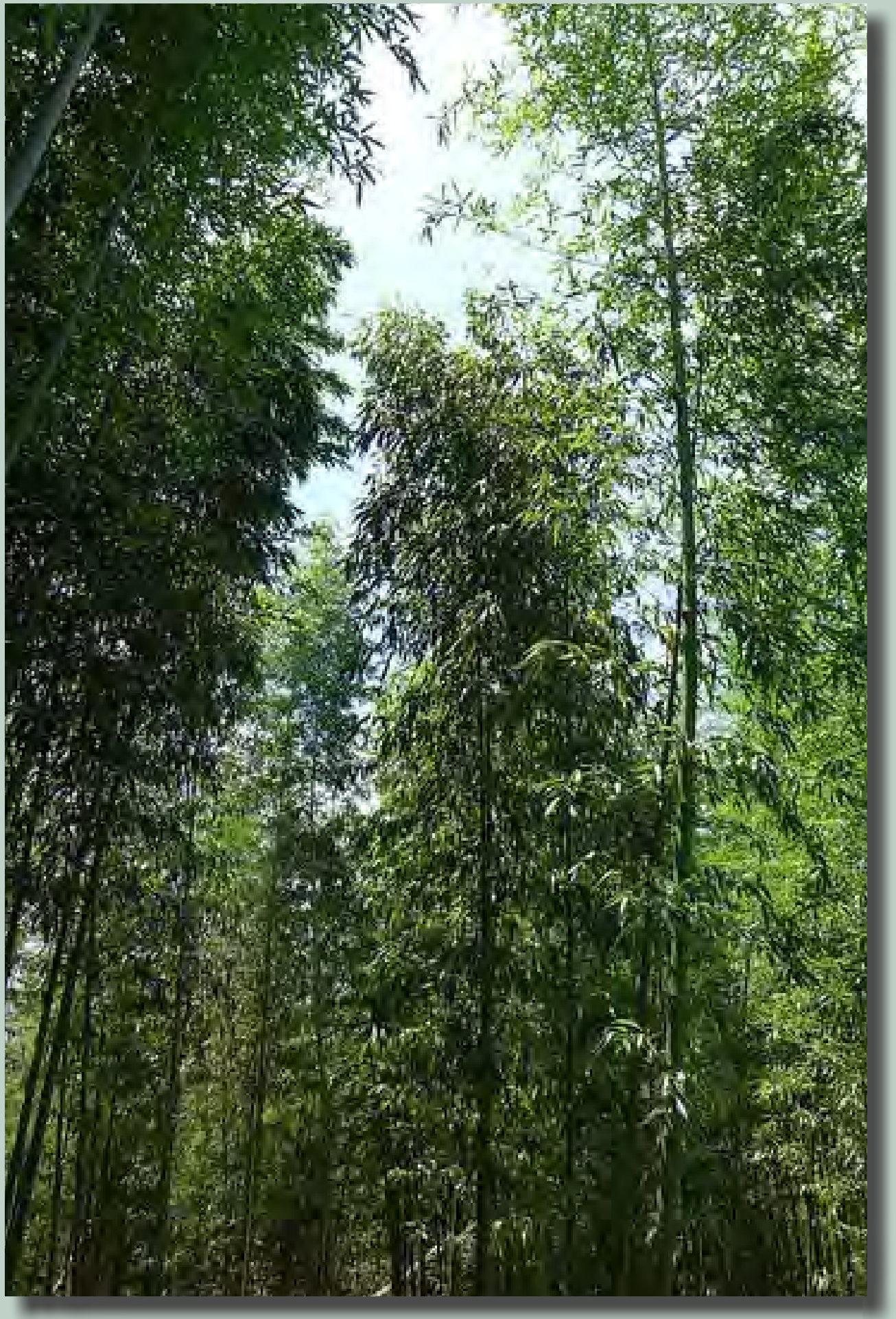

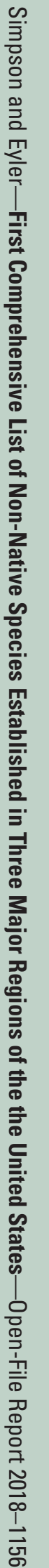

